Article

\title{
Eradication of Candida albicans Biofilm Viability: In Vitro Combination Therapy of Cationic Carbosilane Dendrons Derived from 4-Phenylbutyric Acid with $\mathrm{AgNO}_{3}$ and EDTA
}

\author{
Natalia Gómez-Casanova ${ }^{1}$, Tania Lozano-Cruz ${ }^{2,3,4}$, Juan Soliveri ${ }^{1} \mathbb{D}$, Rafael Gomez $^{2,3,4}$ (D), Paula Ortega $^{2,3,4} \mathbf{D}^{\mathbb{D}}$, \\ José Luis Copa-Patiño ${ }^{1}$ (D) and Irene Heredero-Bermejo ${ }^{1, *(D)}$ \\ 1 Department of Biomedicine and Biotechnology, Faculty of Pharmacy, University of Alcalá, \\ 28871 Alcalá de Henares, Spain; natalia.gomezc@uah.es (N.G.-C.); juan.soliveri@uah.es (J.S.); \\ josel.copa@uah.es (J.L.C.-P.) \\ 2 Department of Organic and Inorganic Chemistry, Research Institute in Chemistry, University of Alcalá, \\ “Andrés M. del Río" (IQAR), 28871 Alcalá de Henares, Spain; tania.lozano@uah.es (T.L.-C.); \\ rafael.gomez@uah.es (R.G.); paula.ortega@uah.es (P.O.) \\ 3 Institute "Ramón y Cajal" for Health Research (IRYCIS), University of Alcalá, 28034 Madrid, Spain \\ 4 Networking Research Center on Bioengineering, Biomaterials and Nanomedicine (CIBER-BBN), \\ 28029 Madrid, Spain \\ * Correspondence: irene.heredero@uah.es
}

Citation: Gómez-Casanova, N.; Lozano-Cruz, T.; Soliveri, J.; Gomez, R.; Ortega, P.; Copa-Patiño, J.L.; Heredero-Bermejo, I. Eradication of Candida albicans Biofilm Viability: In Vitro Combination Therapy of Cationic Carbosilane Dendrons Derived from 4-Phenylbutyric Acid with $\mathrm{AgNO}_{3}$ and EDTA. J. Fungi 2021, 7,574. https://doi.org/10.3390/ jof7070574

Academic Editor: Renátó Kovács

Received: 16 June 2021

Accepted: 15 July 2021

Published: 18 July 2021

Publisher's Note: MDPI stays neutral with regard to jurisdictional claims in published maps and institutional affiliations.

Copyright: (c) 2021 by the authors. Licensee MDPI, Basel, Switzerland. This article is an open access article distributed under the terms and conditions of the Creative Commons Attribution (CC BY) license (https:// creativecommons.org/licenses/by/ $4.0 /)$

\begin{abstract}
Candida albicans is a human pathogen of significant clinical relevance. This pathogen is resistant to different drugs, and most clinical antifungals are not effective against the prevention and treatment of $C$. albicans infections. As with other microorganisms, it can produce biofilms that serve as a barrier against antifungal agents and other substances, contributing to infection in humans and environmental tolerance of this microorganism. Thus, resistances and biofilm formation make treatment difficult. In addition, the complete eradication of biofilms in implants, catheters and other medical devices, is challenging and necessary to prevent relapses of candidemia. Therefore, it is a priority to find new molecules or combinations of compounds with anti-Candida biofilm activity. Due to the difficulty of treating and removing biofilms, the aim of this study was to evaluate the in vitro ability of different generation of cationic carbosilane dendrons derived from 4-phenylbutyric acid, $\mathrm{ArCO}_{2} \mathrm{G}_{n}\left(\mathrm{SNMe}_{3} \mathrm{I}\right)_{\mathrm{m}}$, to eradicate $C$. albicans biofilms. Here, we assessed the antifungal activity of the second generation dendron $\mathrm{ArCO}_{2} \mathrm{G}_{2}\left(\mathrm{SNMe}_{3} \mathrm{I}\right)_{4}$ against $C$. albicans cells and established biofilms since it managed to seriously damage the membrane. In addition, the combinations of the second generation dendron with $\mathrm{AgNO}_{3}$ or EDTA eradicated the viability of biofilm cells. Alterations were observed by scanning electron microscopy and cytotoxicity was assessed on HeLa cells. Our data suggest that the dendritic compound $\mathrm{ArCO}_{2} \mathrm{G}_{2}\left(\mathrm{SNMe}_{3} \mathrm{I}\right)_{4}$ could represent an alternative to control the infections caused by this pathogen.
\end{abstract}

Keywords: Candida albicans; carbosilane dendron; silver nitrate; EDTA; biofilm; synergy

\section{Introduction}

Candida species are frequently found in the normal microbiota of humans. For this reason, it is common to find them in implanted biomaterials and medical instrumentation [1-3], being one of the main causes of catheter-related infections [4] and posing an important health risk for hospitalized patients when biofilm structures are formed [4,5]. The main problems associated to biofilm formation are their greater resistance to antifungal agents, the ability to withstand harsh conditions and the ability of biofilm cells to evade the host's immune response [6]. Consequently, it represents a great challenge for patients with immunodeficiency or medical implanted devices, among others [7]. In addition, another problem lies in the fact that Candida is a eukaryotic microorganism, so the design of new molecules with antifungal activity is limited by the scarcity of targets and the tendency to present 
high cytotoxic levels [8]. Therefore, there is an urgent need to find alternative therapies to prevent and control C. albicans biofilm-related infections. In this sense, dendritic compounds have emerged as an interesting alternative in the field of biomedicine and could be a new therapeutic approach to combat the infections caused by this pathogen [9]. Dendritic systems have well defined and monodisperse structures and are being widely studied in various biomedical fields, such as drug delivery systems, antiviral or magnetic resonance imaging contrast agents, among others $[10,11]$. The properties of these dendrimeric systems such as monodispersity, multivalence, among others, give them the ability to act as drugs. Multivalence allows them to act as therapeutic agents, since the functional groups on the surface are those that interact with cell membranes. Another aspect is their solubility, which makes them of great interest at the clinical level. In their use as antibacterial agents, cationic dendritic molecules have been studied against different planktonic cells [12-15], and biofilms $[9,16]$. In addition, these molecules can overcome the problem of resistances to drugs because it has been reported that they do not induce antibiotic resistance in bacteria [17]. Furthermore, the synergistic combination of these structures with commercial drugs can improve the drug's solubility and the antibacterial activity $[14,18,19]$. In particular, dendritic systems with a conical topology, called dendrons, make it possible to obtain systems with two therapeutic functions, one at the focal point and the other at the surface, in a precise and controlled manner to obtain a dual therapeutic action, for example two therapeutic fragments with different modes of action.

On the other hand, the treatment with different drugs in the so-called combination therapy is interesting from the point of view of reducing the doses to be administered, reducing the side effects of the drugs. Related to the use different compounds in combination therapy, silver is a compound with a low toxicity that is widely used in medicine $[20,21]$. Different salts such as silver nitrate $\left(\mathrm{AgNO}_{3}\right)$, silver diamine fluoride or silver nanoparticles, among others; have a broad antibacterial and antifungal spectrum. In addition, their mechanics of action is consequence of their ability to bind and alter cell membranes, cellular respiration and DNA integrity [22]. Silver has been used in the treatment of wounds [23-25], in water purification [26], caries [21] and biofilms [27], along with other uses. Another compound, that has shown promising results in prevent [28-30] or treat established biofilms [30-32] is ethylenediaminetetraacetic acid (EDTA) either on its own or in combination with commercial antifungal drugs, significantly improving its antibiofilm activity.

In the present study, we investigated the antifungal activity of different generations cationic carbosilane dendrons derived from 4-phenylbutyric acid. In addition, the most active dendron was tested in combination with $\mathrm{AgNO}_{3}$ and EDTA to study their ability to prevent biofilm development or completely eradicate stablished Candida albicans biofilms. The morphological alterations caused by treatment were visualized by scanning electron microscopy (SEM), both in biofilm formation and established biofilms. Finally, the cytotoxicity of cationic carbosilane dendrons derived from 4-phenylbutyric acid were evaluated in a HeLa cell line.

\section{Materials and Methods}

\subsection{Candida Albicans Strain and Culture Conditions}

Candida albicans strain 1002 from Colección Española de Cultivos Tipo (CECT) were used in this study. Candida isolated was stored at $-80^{\circ} \mathrm{C}$ with $20 \%$ glycerol (Sigma-Aldrich, Saint Louis, MO, USA) until use. The strain was grown on Sabouraud chloramphenicol agar (Scharlab, Barcelona, Spain) overnight. To stimulate biofilm formation, various colonies were transferred into Yeast Extract (1\%)-Peptone (2\%)-Dextrose (2\%) (YPD, Scharlab, Barcelona, Spain) and incubated at $37^{\circ} \mathrm{C}$ with agitation (150 rpm) for $24 \mathrm{~h}$.

\subsection{Dendritic Compounds}

Cationic carbosilane dendrons derived from 4-phenylbutyric acid (Sigma-Aldrich, Saint Louis, MO, USA) (Figure 1) soluble in water, were synthesized according to protocol 
described in literature [33]. Three generation of dendrons $\mathrm{ArCO}_{2} \mathrm{G}_{\mathrm{n}}\left(\mathrm{SNMe}_{3} \mathrm{I}\right)_{\mathrm{m}}(\mathrm{n}=1$; $\mathrm{m}=2(\mathbf{1}), \mathrm{n}=2 ; \mathrm{m}=4(2)$ and $\mathrm{n}=3 ; \mathrm{m}=8(3))$ were tested to study their in vitro ability to prevent biofilm formation and eliminate $C$. albicans established biofilms. The antifungal susceptibility testing was performed using the NCCLS M27A broth microdilution reference method [34,35]. Dendrons 1-3 were tested in 96-well microtiter plates using a series of two-fold dilutions with concentrations ranging from 2 to $512 \mathrm{mg} / \mathrm{L}$ against biofilm formation and from 2 to $1024 \mathrm{mg} / \mathrm{L}$ against established biofilms. Plates were incubated at $37^{\circ} \mathrm{C}$. Assays were run in technical triplicate and repeated at least twice in independent experiments. The data were expressed as arithmetic averages.

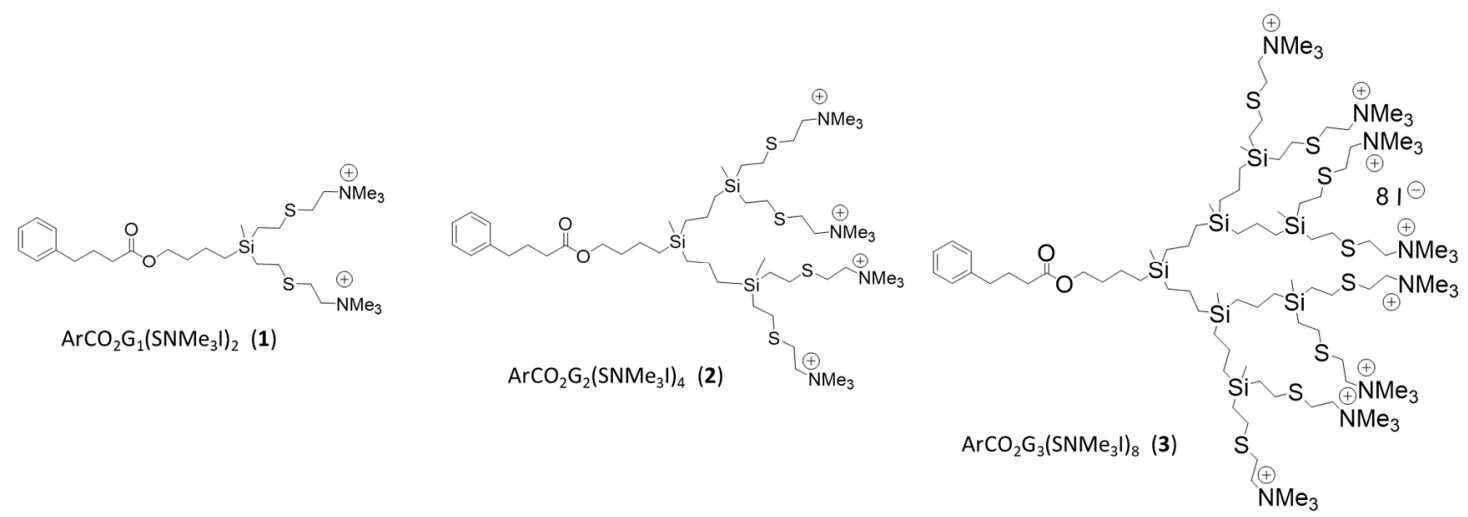

Figure 1. Structures of cationic carbosilane dendrons derived from 4-phenylbutyric acid $\operatorname{ArCO}_{2} \mathrm{G}_{\mathrm{n}}\left(\mathrm{SNMe}_{3} \mathrm{I}\right)_{\mathrm{m}}(\mathrm{n}=1 ; \mathrm{m}=2$ (1), $\mathrm{n}=2 ; \mathrm{m}=4(2)$ and $\mathrm{n}=3 ; \mathrm{m}=8(3)) \mathrm{n}$ : generation, $\mathrm{m}$ : number of functional groups.

\subsection{Antifungal and Antibiofilm Formation Susceptibility Test}

The anti-biofilm activity of dendrons for inhibition of biofilm formation was performed as previously described [9]. An inoculum of $C$. albicans was adjusted to a density equivalent to $0.5 \mathrm{McF}$ arland standard $\left(1 \times 10^{6}\right.$ cells $/ \mathrm{mL}$, Grant Instruments, Royston, UK) in RPMI 1640 medium (Sigma-Aldrich) with morpholinepropanesulfonic acid (MOPS, Sigma-Aldrich) and 2\% glucose (Scharlab, Barcelona, Spain) (RPMI + MOPS + GLU). Then, $50 \mu \mathrm{L}$ of the suspension was inoculated in 96-well microtiter plates containing two-fold serial dilutions of the dendrons ranging from 2 to $512 \mathrm{mg} / \mathrm{L}$. Controls were included in all experiments: un-inoculated medium and dendron free medium. Plates were sealed with Parafilm ${ }^{\circledR}$ (Bemis, Neenah, WI, USA) and incubated for $48 \mathrm{~h}$ at $37^{\circ} \mathrm{C}$. Then, resazurin colorimetric assay (Section 2.6) and drop plate method (Section 2.7) were used to determine the minimum biofilm inhibitory concentration (MBIC) and the minimum fungicidal concentration (MFC), respectively. The MBIC was defined as the lowest concentration at which no growth (resazurin reduction) was observed [9]. The MFC was defined as the lowest concentration for which no growth was observed when plating $5 \mu \mathrm{L}$ suspension of each well, and, in consequence, a biofilm was not formed.

\subsection{In Vitro Antibiofilm Susceptibility Test against Stablished Biofilms}

In vitro biofilm formation was carried out as described above, and plates were incubated for $48 \mathrm{~h}$ at $37^{\circ} \mathrm{C}$ until mature biofilms were formed. At the end of incubation, the medium was carefully aspirated, and biofilms were washed with sterile phosphate buffered saline (PBS, Sigma-Aldrich, Saint Louis, MO, USA) to remove non-adherent cells. Then, serial concentrations of dendritic compounds prepared in RPMI + MOPS + GLU were added to a final volume of $100 \mu \mathrm{L}$ to study the antibiofilm activity (established biofilm). Controls were included in all experiments: un-inoculated medium and dendron free medium. Plates were sealed with Parafilm ${ }^{\circledR}$ and incubated for $48 \mathrm{~h}$ at $37^{\circ} \mathrm{C}$. Then, resazurin colorimetric assay and drop plate method were used to determine the minimum biofilm damaging concentrations (MBDC) and the minimum biofilm eradicating concentration (MBEC), respectively. These assays determined the inhibition of established biofilms. The MBDC was 
defined as the lowest concentration that caused damage and affected or inhibited Candida metabolic activity. For these experiments, MBDC value has a similar meaning as the classic MIC, with the difference that these cells have developed a biofilm and we assume that most of them are damaged (detection by resazurin as non-viable, not absorbance signal detected). The MBEC was defined as the lowest concentration resulting in a $100 \%$ cell death of the biofilm (no growth observed on agar plates), therefore, biofilm cells were not viable $[9,36]$.

\subsection{Combination Therapy of Dendron $\mathrm{ArCO}_{2} \mathrm{G}_{2}\left(\mathrm{SNMe}_{3} \mathrm{I}_{4}\right.$ (2) with $\mathrm{AgNO}_{3}$ and EDTA against C. albicans}

The potential synergistic activity was studied for the biofilm formation and established biofilm conditions using the checkerboard titration technique [37]. Silver nitrate $\left(\mathrm{AgNO}_{3}\right)$ (Sigma-Aldrich, Saint Louis, MO, USA) and ethylenediaminetetraacetic acid (EDTA) (Sigma-Aldrich, Saint Louis, MO, USA) were used in combination with the most effective dendron tested $\mathrm{ArCO}_{2} \mathrm{G}_{2}\left(\mathrm{SNMe}_{3} \mathrm{I}\right)_{4}$ (2). The concentrations used to treat biofilm formation (Section 2.3) ranged from 1 to $32 \mathrm{mg} / \mathrm{L}$ for $\mathrm{ArCO}_{2} \mathrm{G}_{2}\left(\mathrm{SNMe}_{3} \mathrm{I}\right)_{4}$ (2), from 0.5 to $16 \mathrm{mg} / \mathrm{L}$ for $\mathrm{AgNO}_{3}$ and from 8 to $256 \mathrm{mg} / \mathrm{L}$ for EDTA. For stablished biofilms (Section 2.4), the concentrations ranged from 32 to $1024 \mathrm{mg} / \mathrm{L}$ for $\mathrm{ArCO}_{2} \mathrm{G}_{2}\left(\mathrm{SNMe}_{3} \mathrm{I}\right)_{4}$ (2), from 32 to $1048 \mathrm{mg} / \mathrm{L}$ for $\mathrm{AgNO}_{3}$ and from 16 to $512 \mathrm{mg} / \mathrm{L}$ for EDTA. After treatments, resazurin assay and drop plate method were used as described in Sections 2.6 and 2.7 to determine the MBIC, MBDC, MFC and MBEC values.

\subsection{Resazurin Assay}

Resazurin (Sigma-Aldrich) solution at $0.01 \%(w / v)$ was prepared in sterile distilled water $[9,38,39]$. The solution was filtered using a $0.22-\mu \mathrm{m}$-pore-size filter, and conserved at $4{ }^{\circ} \mathrm{C}$. After treatment and incubation times, each well was washed with PBS, and then $20 \mu \mathrm{L}$ resazurin was added to each well containing $100 \mu \mathrm{L}$ of PBS. Plates were incubated in the dark at $37^{\circ} \mathrm{C}$ for $24 \mathrm{~h}$. Absorbance was measured at 570 and $600 \mathrm{~nm}$ in a microplate reader $\left(\mathrm{Epoch}^{\mathrm{TM}}\right.$, BioTek Instruments Inc, Winooski, VT, USA).

These assays were used to determine the MBIC values (in the biofilm formation experiments) and the MBDC values (in the established biofilm experiments).

\subsection{Drop Plate Method}

For these assays, biofilms were scraped and $5 \mu \mathrm{L}$ suspensions were transferred onto Chloramphenicol-Sabouraud agar plates (Scharlab, Barcelona, Spain). All plates were incubated for $24 \mathrm{~h}$ at $37^{\circ} \mathrm{C}$. However, they were incubated for additional $24 \mathrm{~h}$ at $37^{\circ} \mathrm{C}$ and let at room temperature for other $48 \mathrm{~h}$ when growth was not observed.

The MFC values (in the biofilm formation experiments) and the MBEC values (in the established biofilm experiments) were obtained by the drop plate method [40]. These values were determined at concentrations where growth was not observed.

\subsection{Cytotoxicity Evaluation}

The cytotoxicity was studied for the most efficient dendron and combinations against this strain of $C$. albicans. The cytotoxicity was evaluated using HeLa cells (ATCC ${ }^{\circledR}$ CCL2TM). Assays were performed in 24-well plates (NUNCTM) in Dulbecco's Modified Eagle Medium supplemented with 10\% foetal bovine serum (Sigma-Aldrich Ltd.) and 1\% antibiotic mix: $10.000 \mathrm{U}$ penicillin, $10 \mathrm{mg}$ streptomycin and $25 \mu \mathrm{g}$ AmB per mL (Sigma-Aldrich Ltd.). Cells were seeded at a density of $1 \times 10^{4}$ cells / well in $500 \mu \mathrm{L}$ of fresh medium. Plates were incubated at $37^{\circ} \mathrm{C}$ in a $5 \% \mathrm{CO}_{2}$ atmosphere for 5 days, until a confluent monolayer was formed. At the end of incubation time, the medium was replaced by $400 \mathrm{uL}$ of the serial concentrations of each compound (dendron, $\mathrm{AgNO}_{3}$ and EDTA) or combinations of compounds (dendron- $\mathrm{AgNO}_{3}$ and dendron-EDTA), diluted in fresh medium. Control wells received $400 \mu \mathrm{L}$ of fresh medium. After $48 \mathrm{~h}$ of incubation, the culture medium was discarded, wells were washed three times with PBS and $500 \mu \mathrm{L}$ of medium were added to each well. To evaluate the cytotoxicity, each well received $50 \mu \mathrm{L}$ of microculture 
tetrazolium (MTT, $5 \mathrm{mg} / \mathrm{mL}$ ) (Sigma-Aldrich Ltd.) and plates were incubated for $4 \mathrm{~h}$ at $37^{\circ} \mathrm{C}$. Subsequently, medium was discarded and $500 \mu \mathrm{L}$ of dimethyl sulfoxide were added to dissolve formazan crystals. Absorbance values were recorded in a microplate absorbance reader at $570 \mathrm{~nm}$ (BioTek Instruments Inc. Model: ELX 800). Experiments were performed in triplicate and repeated at least twice.

Viability percentage was calculated as $\mathrm{OD}_{570}$ compound/OD 570 control $\times 100$ (control wells were considered $100 \%$ ). Reduction in viability percentages $<10 \%$ were considered noncytotoxic, values between $10-25 \%$ were considered low cytotoxicity, and values between $25-40 \%$ were considered moderate cytotoxicity levels [41].

\subsection{Ultrastructural Study}

The cell damage in C. albicans biofilm structures was evaluate using scanning electron microscopy (SEM). Sublethal concentrations were tested, and untreated controls were included. Morphological differences between biofilms treated with $\mathrm{ArCO}_{2} \mathrm{G}_{2}\left(\mathrm{SNMe}_{3} \mathrm{I}\right)_{4}$ (2), and the dendron in combination with EDTA and $\mathrm{AgNO}_{3}$ were evaluated. Both the biofilm formation and established biofilm treatment samples were studied.

C. albicans was grown on a glass coverslip as explained above for the biofilm assays. Milloning's solution containing $2 \%$ glutaraldehyde was used to fix the biofilm. In this case, $24 \mathrm{~h}$ later, cells were washed in Milloning's solution with glucose (0.5\%) [9]. Each glass coverslip was dehydrated in graded series of ethanol $(30 \%-50 \%-70 \%-95 \%-100 \%)$, and then in anhydrous acetone, incubating for 7 min each. A Polaron CPD7501 critical-point drying system, and $200 \AA$ Å gold-palladium sputter coating by Polaron E5400 were used on the samples. SEM was performed in a Zeiss DSM 950 microscope at $5-15 \mathrm{kV}$. The samples were prepared in triplicate, and different fields were observed for each sample.

\subsection{Statistical Analysis}

All experiments were performed in triplicate. Two-way analysis of variance (ANOVA) and post-hoc comparisons with Dunnett's multiple comparison tests were used to evaluate significance of differences. Statistical significance was defined as $p<0.05$. Analysis was carried out using GraphPad Prism $9^{\circledR}$ (GraphPad Software, San Diego, CA, USA).

\section{Results and Discussion}

\subsection{Effective Prevention of C. albicans Biofilm Formation}

Cationic carbosilane systems of different topology (spherical, wedge and bow-tie) have been describes as a antibacterial compound with a broad spectrum of action due to the presence of the ammonium groups on the surface (positive charge). The dendritic compounds used in this work are cationic carbosilane dendrons derived from 4-phenylbutyric acid. The principal differences between them are their generation that determine the number of ammonium groups on the surface. The increase in dendritic generation determines the hydrophilic/hydrophilic balance of the generated systems, which increases with increasing generation and determines how they interact with the cell membrane [17]. These dendrons present a 4-phenylbutyric acid (PBA) moiety at the focal point. PBA is drug used for urea cycle disorders and its effects on microorganisms are poorly studied [42]. However, some assays have shown that it can reduce Shigella infection in vivo using animal models [43], reduce colonization by Salmonella enterica serovar Typhimurium [44], inhibit the growth of Helicobacter pylori and Escherichia coli [45] and reduce herpes simplex virus infection [46]; among others. One of their advantages is also their solubility in water, thus overcome the issues generated by some antifungals that have the disadvantage of poor solubility [47].

The results obtained indicate that these compounds showed an antifungal activity against $C$. albicans and exerted activity preventing biofilm formation (Table 1 ) and the second generation dendrimer dendron $\mathrm{ArCO}_{2} \mathrm{G}_{2}\left(\mathrm{SNMe}_{3} \mathrm{I}\right)_{4}$ (2) with 4 positive charges was the most active molecule preventing $C$. albicans biofilm formation among all dendron tested. 
Table 1. Antifungal activity against $C$. albicans CECT1002 of compounds $\mathbf{1}-\mathbf{3}$ in biofilm formation (MBIC and MFC * (mg/L)) and in stablished biofilm (MBDC and MBEC * (mg/L)).

\begin{tabular}{ccccc}
\hline \multirow{2}{*}{ Dendrons } & \multicolumn{2}{c}{ Biofilm Formation } & \multicolumn{2}{c}{ Stablished Biofilm } \\
\cline { 2 - 5 } & MBIC (mg/L) & MFC * $(\mathbf{m g} / \mathbf{L})$ & MBDC $(\mathbf{m g} / \mathbf{L})$ & MBEC * $(\mathbf{m g} / \mathrm{L})$ \\
\hline $\mathrm{ArCO}_{2} \mathrm{G}_{1}\left(\mathrm{SNMe}_{3} \mathrm{I}\right)_{2}(\mathbf{1})$ & 256 & 256 & $>1024$ & $\mathrm{BNE}$ \\
$\mathrm{ArCO}_{2} \mathrm{G}_{2}\left(\mathrm{SNMe}_{3} \mathrm{I}\right)_{4}(\mathbf{2})$ & 16 & 16 & 64 & $\mathrm{BNE}$ \\
$\mathrm{ArCO}_{2} \mathrm{G}_{3}\left(\mathrm{SNMe}_{3} \mathrm{I}\right)_{8}(\mathbf{3})$ & 256 & 256 & 256 & $\mathrm{BNE}$ \\
$\mathrm{AgNO}_{3}$ & 8 & $8-16$ & 32 & $\mathrm{BNE}$ \\
$\mathrm{EDTA}$ & $>512$ & $>512$ & $>1024$ & $\mathrm{BNE}$ \\
\hline
\end{tabular}

BNE: Biofilm not eradicated. ${ }^{*}$ Drop plate method. MBIC: minimum biofilm inhibitory concentration. MFC: minimum fungicidal concentration. MBDC: minimum biofilm damaging concentrations. MBEC: minimum biofilm eradicating concentration.

For $C$. albicans CECT 1002, the MBIC and MFC values were $16 \mathrm{mg} / \mathrm{L}$ using $\mathrm{ArCO}_{2} \mathrm{G}_{2}$ $\left(\mathrm{SNMe}_{3} \mathrm{I}\right)_{4}(\mathbf{2})$; however, the $\mathrm{ArCO}_{2} \mathrm{G}_{1}\left(\mathrm{SNMe}_{3} \mathrm{I}\right)_{2}$ (1) and $\mathrm{ArCO}_{2} \mathrm{G}_{3}\left(\mathrm{SNMe}_{3} \mathrm{I}\right)_{8}$ (3) dendrons had an MBIC and MFC value of $256 \mathrm{mg} / \mathrm{L}$ (Table 1). Even though they showed the same MBIC value, a reduction to $55.55 \pm 7.48 \%$ in viability percentage was observed with $16 \mathrm{mg} / \mathrm{L}$ concentration when the dendron $\mathrm{ArCO}_{2} \mathrm{G}_{3}\left(\mathrm{SNMe}_{3} \mathrm{I}\right)_{8}(3)$ was used, and $98.62 \pm 2.75 \%$ when the dendron $\mathrm{ArCO}_{2} \mathrm{G}_{1}\left(\mathrm{SNMe}_{3} \mathrm{I}\right)_{2}(\mathbf{1})(p<0.001)$ (Figure 2A). In addition, Candida viability remained at $98.06 \pm 3.00 \%$ using $\mathrm{ArCO}_{2} \mathrm{G}_{1}\left(\mathrm{SNMe}_{3} \mathrm{I}\right)_{2}(\mathbf{1})$ at $64 \mathrm{mg} / \mathrm{L}$ $(p>0.05)$ while it was reduced to $23.06 \pm 5.56 \%(p<0.001)$ when $\mathrm{ArCO}_{2} \mathrm{G}_{3}\left(\mathrm{SNMe}_{3} \mathrm{I}\right)_{8}$ (3) was tested at $64 \mathrm{mg} / \mathrm{L}$ (Figure 2). However, we did not observe a gradual increasing antifungal activity with increasing generation, because the most active compound was $\mathrm{ArCO}_{2} \mathrm{G}_{2}\left(\mathrm{SNMe}_{3} \mathrm{I}\right)_{4}$ (2) (generation 2), that reduced viability completely. This is in agreement with previously results described in the literature due to the importance of the hydrophilicity-hydrophobicity balance in the dendritic skeleton that determine the efficiency-generation relationship $[17,48]$. In addition, higher generations also showed a greater cytotoxicity [17].

\section{Biofilm formation}

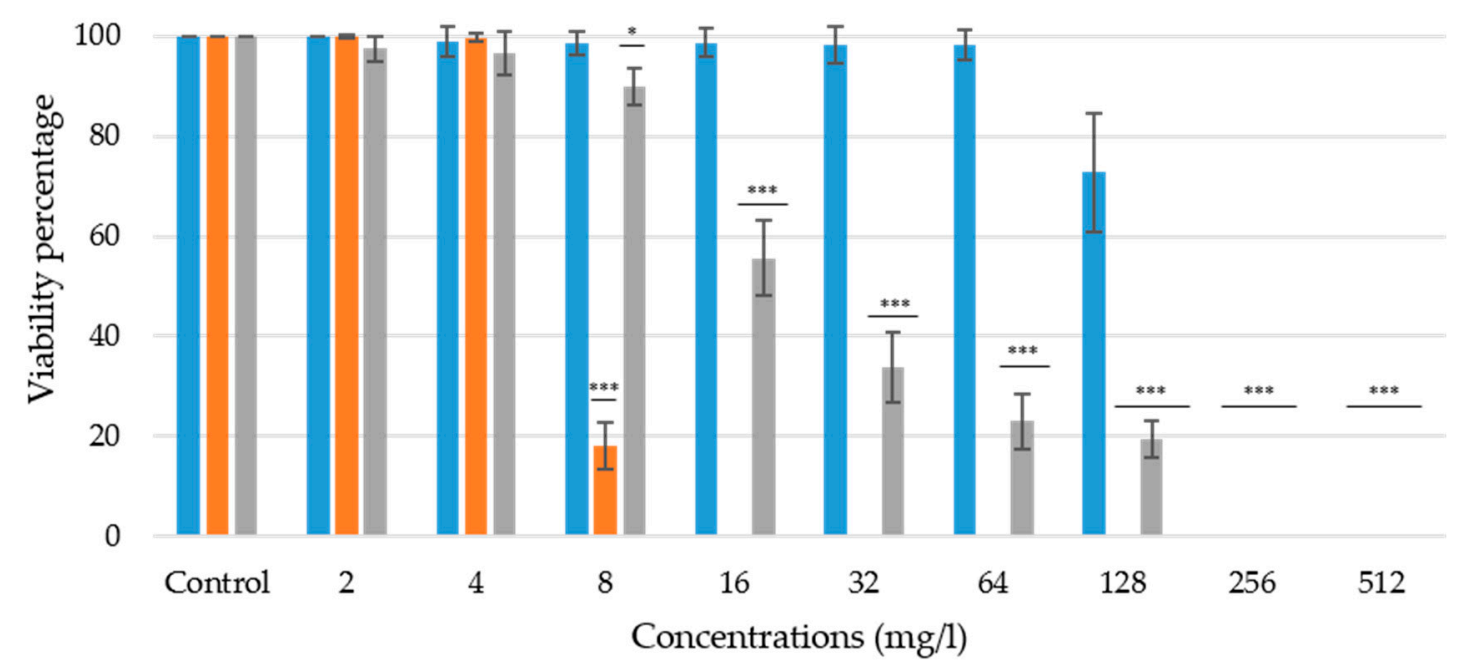

Figure 2. Cont. 
(B)

\section{Established biofilm}

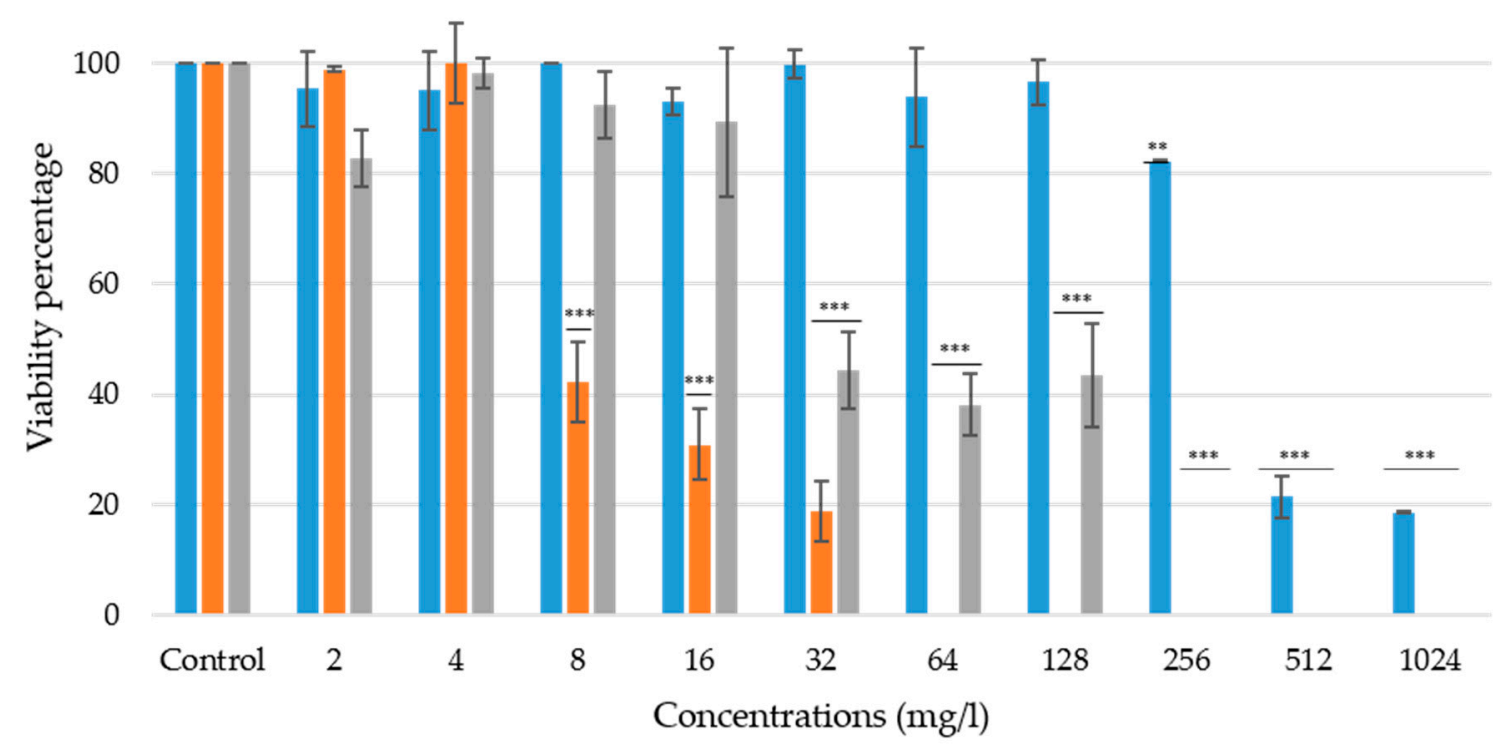

Figure 2. $\mathrm{ArCO}_{2} \mathrm{G}_{1}\left(\mathrm{SNMe}_{3} \mathrm{I}\right)_{2}$ (1)—blue, $\mathrm{ArCO}_{2} \mathrm{G}_{2}\left(\mathrm{SNMe}_{3} \mathrm{I}\right)_{4}$ (2)—orange, $\mathrm{ArCO}_{2} \mathrm{G}_{3}\left(\mathrm{SNMe}_{3} \mathrm{I}\right)_{8}$ (3)—grey. (A) Antifungal activity and inhibition of the formation of C. albicans biofilm in the biofilm formation experiments, (B) Antibiofilm activity against stablished biofilms in the established biofilm experiments. $p$ values: ${ }^{*} p<0.05,{ }^{* *} p<0.01,{ }^{* * *} p<0.001$.

Our data demonstrated that $\mathrm{ArCO}_{2} \mathrm{G}_{2}\left(\mathrm{SNMe}_{3} \mathrm{I}\right)_{4}$ (2) antifungal activity (MBIC and MFC $=16 \mathrm{mg} / \mathrm{L}$ ) was similar to the in vitro values required for some antifungals commonly used for C. albicans, such as amphotericin [49]. Some antifungals, such as fluconazole, facilitates the development of resistance due fungistatic conditions [50]. However, dendritic systems have been previously described to not generate resistance [17]. In our case, the $\mathrm{ArCO}_{2} \mathrm{G}_{2}\left(\mathrm{SNMe}_{3} \mathrm{I}\right)_{4}$ (2) antifungal and antibiofilm activity may be due to the mode of action proposed for these types of polycationic molecules related to their ability to interact with and penetrate the negatively charged membranes. This interaction removes divalent cations that maintain membrane integrity, modifying membrane permeability and leading to its disintegration $[17,51,52]$. Dendritic molecules target different cell structures and cause several metabolic disruptions, such as membrane disruption, membrane depolarization or cell cycle arrest $[11,53]$. In our previous studies, this effect was observed by SEM, including the formation of pores in the membrane of C. albicans [9]. These concurrent damages cause Candida cells to have decreased viability and reduce their ability to withstand the effects produced by treatments [54]. In contrast, the mode of action of antifungals is by targeting specific molecules or cell structures.

\subsection{Antibiofilm Activity against Established Biofilms}

C. albicans has the potential to form biofilms in different surfaces, and this fact increases the resistance of these fungi to antifungals. As anticipated by the results obtained in the study of the dendrons activity in the biofilm formation, the results obtained in the treatment of already formed biofilms showed that the activity of $\mathrm{ArCO}_{2} \mathrm{G}_{3}\left(\mathrm{SNMe}_{3} \mathrm{I}\right)_{8}$ (3) and $\mathrm{ArCO}_{2} \mathrm{G}_{1}\left(\mathrm{SNMe}_{3} \mathrm{I}\right)_{2}$ (1) dendrons was less effective at damaging the established biofilms (MBDC value of $256 \mathrm{mg} / \mathrm{L}$ and $>1024 \mathrm{mg} / \mathrm{L}$, respectively) when compared to the $\mathrm{ArCO}_{2} \mathrm{G}_{2}\left(\mathrm{SNMe}_{3} \mathrm{I}\right)_{4}$ (2) dendron which damaged the biofilm at a concentration of $64 \mathrm{mg} / \mathrm{L}$ (MBDC) (Table 1) $(p<0.001)$. In addition, viability was reduced to $50 \%$ at a concentration of $8 \mathrm{mg} / \mathrm{L}(p<0.001)$ (Figure 2B). As expected, these values were all higher than our MBIC values; however, they were able to damage biofilms. In contrast, we did not reach the MBEC values for any of the dendrons tested, as growth was observed at 
all the concentrations in the drop plate method. We found cells that persisted when cell suspensions were plated on agar plates $[55,56]$. Similar results were described in our previous study. A spherical dendrimer of generation 0 that containing a tetrasiloxane $\left([\mathrm{SiO}]_{4}\right)$ core four $-\mathrm{NMe}_{3}{ }^{+}$terminal groups on the periphery (named BDSQ024) showed a MFC of $32 \mathrm{mg} / \mathrm{L}$ and was not able to eliminate $100 \%$ of the viable cells from the stablished biofilm of C. albicans (MBEC was not determined) [9]. Despite not being a dendron tested in that study, the dendron $\mathrm{ArCO}_{2} \mathrm{G}_{2}\left(\mathrm{SNMe}_{3} \mathrm{I}\right)_{4}$ (2) shares some characteristics with the BDSQ024 dendrimer, including the presence of $4 \mathrm{NMe}^{3+}$ groups on its surface (cationic molecule) and $\mathrm{Si}$ and $\mathrm{S}$ in its structure. Even though the rest of the molecular structure is completely different, knowing the importance of the presence of a certain number of exposed charges could be key when developing new compounds. It is also important to remark, that these dendritic molecules may not generate drug resistance in microbial cells. This may be due to their positive charge that interacts with the negatively charged cell surface and not with a specific organelle, protein or other molecule [53]. Further studies would be conducted by our research group to determine their exact mode of action.

\subsection{Combined Activity of $\mathrm{ArCO}_{2} \mathrm{G}_{2}\left(\mathrm{SNMe}_{3} \mathrm{I}_{4}\right.$ (2) and $\mathrm{AgNO}_{3}$}

The synergistic effect between $\mathrm{AgNO}_{3}$ and $\mathrm{ArCO}_{2} \mathrm{G}_{2}\left(\mathrm{SNMe}_{3} \mathrm{I}\right)_{4}$ (2), the most effective dendron, was evaluated to determine if combination therapy might improve its efficacy and reduce the effective concentration. In the biofilm formation experiments, it was observed that the combination of both compounds exhibited a strong activity preventing biofilm formation. For instance, the combination $8: 4 \mathrm{mg} / \mathrm{L}\left(\mathrm{ArCO}_{2} \mathrm{G}_{2}\left(\mathrm{SNMe}_{3} \mathrm{I}\right)_{4}(2): \mathrm{AgNO}_{3}\right)$ reduced the $C$. albicans cell viability to $11.61 \pm 2.58 \%$. A reduction of $51.13 \pm 12.7 \%$ was achieved when combining a lower concentration of $\mathrm{AgNO}_{3}(0.5 \mathrm{mg} / \mathrm{L})$ with $8 \mathrm{mg} / \mathrm{L}$ of $\mathrm{ArCO}_{2} \mathrm{G}_{2}\left(\mathrm{SNMe}_{3} \mathrm{I}\right)_{4}$ (2) (Table 2). However, the MFC values obtained for the compounds in individual assays were not reduced in any case when combinations were analysed.

Table 2. Viability percentage of cells forming Candida biofilms. The minimum fungicidal concentration (MFC) and minimum biofilm eradicating concentration (MBEC) values for the different combinations of $\mathrm{ArCO}_{2} \mathrm{G}_{2}\left(\mathrm{SNMe}_{3} \mathrm{I}\right)_{4}(2)-\mathrm{AgNO} 3$ and $\mathrm{ArCO}_{2} \mathrm{G}_{2}\left(\mathrm{SNMe}_{3} \mathrm{I}\right)_{4}(2)$-EDTA are indicated.

\begin{tabular}{|c|c|c|c|c|c|c|}
\hline \multirow{4}{*}{$\begin{array}{l}\text { Biofilm } \\
\text { formation }\end{array}$} & \multicolumn{3}{|c|}{$\mathrm{ArCO}_{2} \mathrm{G}_{2}\left(\mathrm{SNMe}_{3} \mathrm{I}\right)_{4}(2)$ and $\mathrm{AgNO}_{3}$} & \multicolumn{3}{|c|}{$\mathrm{ArCO}_{2} \mathrm{G}_{2}\left(\mathrm{SNMe}_{3} \mathrm{I}\right)_{4}(2)$ and EDTA } \\
\hline & (2): $\mathrm{AgNO}_{3}(\mathrm{mg} / \mathrm{L})$ & Viability \% & MFC* & (2):EDTA (mg/L) & Viability\% & $\mathrm{MFC}^{*}$ \\
\hline & $8: 4$ & $11.61 \pm 2.58 \%$ & BNE & $8: 256(\mathrm{MFC})$ & $0.00 \pm 0.00 \%$ & $\mathrm{BE}$ \\
\hline & $8: 0.5$ & $51.13 \pm 12.7 \%$ & $\mathrm{BNE}$ & $8: 32$ & $24.08 \pm 7.32 \%$ & $\mathrm{BNE}$ \\
\hline \multirow{3}{*}{$\begin{array}{l}\text { Established } \\
\text { biofilm }\end{array}$} & \multicolumn{3}{|c|}{$\mathrm{ArCO}_{2} \mathrm{G}_{2}\left(\mathrm{SNMe}_{3} \mathrm{I}\right)_{4}(2)$ and $\mathrm{AgNO}_{3}$} & \multicolumn{3}{|c|}{$\mathrm{ArCO}_{2} \mathrm{G}_{2}\left(\mathrm{SNMe}_{3} \mathrm{I}\right)_{4}(2)$ and EDTA } \\
\hline & (2): $\mathrm{AgNO}_{3}(\mathrm{mg} / \mathrm{L})$ & Viability \% & MBEC * & (2):EDTA (mg/L) & Viability\% & MBEC * \\
\hline & 32:32 (MBEC) & $0 \pm 0.00 \%$ & $\mathrm{BE}$ & $\begin{array}{c}256: 16(\mathrm{MBEC}) \\
32 \cdot 16\end{array}$ & $\begin{array}{c}0 \pm 0.00 \% \\
4259+3.4 \%\end{array}$ & $\begin{array}{c}\mathrm{BE} \\
\mathrm{BNE}\end{array}$ \\
\hline
\end{tabular}

BNE: Biofilm not eradicated. BE: Biofilm eradicated. * Drop plate method.

Regarding the effect of the compounds in the already formed biofilm experiments (established biofilms), $\mathrm{AgNO}_{3}$ tested independently (Table 2) was able to damage the biofilm cells. However, it did not manage to disrupt and completely eliminate the viability of the biofilm cells at the concentration of $1024 \mathrm{mg} / \mathrm{L}$ (MBEC) (same as observed with $\left.\mathrm{ArCO}_{2} \mathrm{G}_{2}\left(\mathrm{SNMe}_{3} \mathrm{I}\right)_{4}(2)\right)$. The MFC and MBEC values included in Table 2 represent the combinations of $\left(\mathrm{ArCO}_{2} \mathrm{G}_{2}\left(\mathrm{SNMe}_{3} \mathrm{I}\right)_{4} 2\right)-\mathrm{AgNO}_{3}$ and (2)-EDTA that eradicated cell viability.

Silver has extracellular and intracellular binding properties. Therefore, this molecule has the ability to bind to the microbial wall and, once it enters the cell, to bind to and damage proteins, genetic material or denature cytoplasmic enzymes, among other effects [21,22]. Additionally, this type of dendron also binds to the negatively charged cell membranes due to electrostatic interactions causing destabilization of the membrane, enhancing its effectiveness against established biofilms. Indeed, the combination therapy was able to completely kill cells and eradicate an established biofilm at a much lower concentration of 
$32 \mathrm{mg} / \mathrm{L}$ of $\mathrm{AgNO}_{3}$ and $32 \mathrm{mg} / \mathrm{L}$ of $\mathrm{ArCO}_{2} \mathrm{G}_{2}\left(\mathrm{SNMe}_{3} \mathrm{I}\right)_{4}$ (2) (Table 2). The anti-microbial effect of silver has been reported previously by other authors against planktonic cells and biofilms $[21,27,57,58]$.

\subsection{Combined Activity of $\mathrm{ArCO}_{2} \mathrm{G}_{2}\left(\mathrm{SNMe}_{3} \mathrm{I}_{4}\right.$ (2) and EDTA}

The synergistic effect between EDTA and $\mathrm{ArCO}_{2} \mathrm{G}_{2}\left(\mathrm{SNMe}_{3} \mathrm{I}\right)_{4}$ (2) was also evaluated. In individual biofilm formation treatment experiments, $\mathrm{ArCO}_{2} \mathrm{G}_{2}\left(\mathrm{SNMe}_{3} \mathrm{I}\right)_{4}(2)$ had a MFC of $16 \mathrm{mg} / \mathrm{L}$ and the EDTA failed to kill $100 \%$ of the cells at any concentration tested. The results obtained in the combination of $\mathrm{ArCO}_{2} \mathrm{G}_{2}\left(\mathrm{SNMe}_{3} \mathrm{I}\right)_{4}(2)$ and EDTA indicate that it was possible to reduce the MFC value for both compounds using $8 \mathrm{mg} / \mathrm{L}$ and $256 \mathrm{mg} / \mathrm{L}$, respectively. In addition, using less concentrated EDTA $(32 \mathrm{mg} / \mathrm{L})$ it was possible to reduce C. albicans viability to $24.08 \pm 7.32 \%$ (Table 2 ).

Regarding the established biofilm treatment, promising results were also found when EDTA was studied in combination with $\mathrm{ArCO}_{2} \mathrm{G}_{2}\left(\mathrm{SNMe}_{3} \mathrm{I}\right)_{4}$ (2). In this case, we again managed to eradicate the viability of the biofilm cells completely; however, higher concentration of $\mathrm{ArCO}_{2} \mathrm{G}_{2}\left(\mathrm{SNMe}_{3} \mathrm{I}\right)_{4}$ (2) compound was required for established biofilms (Table 2). Even though, we verified that using a combination of 32:16 $\left(\mathrm{ArCO}_{2} \mathrm{G}_{2}\left(\mathrm{SNMe}_{3} \mathrm{I}\right)_{4}\right.$ (2)-EDTA) was able to reduce viability to $42.59 \pm 3.40 \%$ of the cells forming the biofilm (Table 2). EDTA is a chelating agent that is used as an aseptic agent, enhancing the activity of other compounds, even in wound dressings for the control of microorganisms [31]. In yeast, it is believed that the mechanism of action presented by EDTA is related to the formation of complexes with certain ions $\left(\mathrm{Mg}^{2+}\right.$ and $\left.\mathrm{Ca}^{2+}\right)$, inhibiting cell growth and causing its death [31]. In vitro eradication of Candida spp. biofilms using minocycline-EDTA-ethanol antimicrobial catheter lock solution has been reported $[59,60]$.

\subsection{Cytotoxicity}

The cytotoxicity of the $\mathrm{ArCO}_{2} \mathrm{G}_{2}\left(\mathrm{SNMe}_{3} \mathrm{I}\right)_{4}$ (2) dendron and the combinations tested in this research were studied in Hela cells. Our data indicated that $16 \mathrm{mg} / \mathrm{L} \mathrm{ArCO}_{2} \mathrm{G}_{2}\left(\mathrm{SNMe}_{3} \mathrm{I}\right)_{4}$ (2), the MBIC and MFC values for this dendron, showed high cytotoxicity at $48 \mathrm{~h}$ treatment. On the other hand, $\mathrm{AgNO}_{3}$ was highly cytotoxic at the concentrations ranging from 4 to $256 \mathrm{mg} / \mathrm{L}$ (MBIC $8 \mathrm{mg} / \mathrm{L}$ and MFC 8-16 mg/L), and EDTA showed no cytotoxicity at the concentrations ranging from 16 to $128 \mathrm{mg} / \mathrm{L}$, but low cytotoxicity was observed at $256 \mathrm{mg} / \mathrm{L}$ EDTA (MBIC and MFC > $1024 \mathrm{mg} / \mathrm{L}$ ). Therefore, it is shown that $\mathrm{AgNO}_{3}$ cytotoxicity was higher than EDTA cytotoxicity.

The cytotoxic effects were also studied on compounds and concentrations used in combinations that affected the biofilm formation and established biofilm treatments (Table 3). In the biofilm formation-treatment, our data indicated that the effective combination $\mathrm{ArCO}_{2} \mathrm{G}_{2}\left(\mathrm{SNMe}_{3} \mathrm{I}\right)_{4}$ (2):EDTA (8:256) showed cytotoxicity (MFC combination value). In addition, the combination $\mathrm{ArCO}_{2} \mathrm{G}_{2}\left(\mathrm{SNMe}_{3} \mathrm{I}\right)_{4}$ (2):EDTA (8:32), that reduced biofilm viability to $24.08 \pm 7.32 \%$, and the combination $\mathrm{ArCO}_{2} \mathrm{G}_{2}\left(\mathrm{SNMe}_{3} \mathrm{I}\right)_{4}(2): \mathrm{AgNO}_{3}$ (8:0.5), that reduced biofilm viability to $51.13 \pm 12.7 \%$, showed moderate and high cytotoxicity, respectively. We remark that combinations achieved a reduction in compound concentrations with an increase in activity and a significant reduction in cell cytotoxicity.

Table 3. Viability percentage of HeLa cells treated with combinations.

\begin{tabular}{cc}
\hline Combination & Viability\% \\
\hline $\mathrm{ArCO}_{2} \mathrm{G}_{2}\left(\mathrm{SNMe}_{3} \mathrm{I}\right)_{4}(\mathbf{2}): \mathrm{AgNO}_{3}(32: 32)$ & $1.32 \pm 0.63$ \\
$\mathrm{ArCO}_{2} \mathrm{G}_{2}\left(\mathrm{SNMe}_{3} \mathrm{I}\right)_{4}(2): \operatorname{AgNO}_{3}(8: 4)$ & $1.72 \pm 0.68$ \\
$\mathrm{ArCO}_{2} \mathrm{G}_{2}\left(\mathrm{SNMe}_{3} \mathrm{I}\right)_{4}(2): \operatorname{AgNO}_{3}(8: 0.5)$ & $51.91 \pm 3.73$ \\
$\mathrm{ArCO}_{2} \mathrm{G}_{2}\left(\mathrm{SNMe}_{3} \mathrm{I}\right)_{4}(2): \mathrm{EDTA}_{(256: 16)}$ & $1.73 \pm 0.10$ \\
$\mathrm{ArCO}_{2} \mathrm{G}_{2}\left(\mathrm{SNMe}_{3} \mathrm{I}\right)_{4}(2): \mathrm{EDTA}(32: 16)$ & $7.85 \pm 0.21$ \\
$\mathrm{ArCO}_{2} \mathrm{G}_{2}\left(\mathrm{SNMe}_{3} \mathrm{I}\right)_{4}(2):$ EDTA (8:256) & $56.46 \pm 4.35$ \\
$\mathrm{ArCO}_{2} \mathrm{G}_{2}\left(\mathrm{SNMe}_{3} \mathrm{I}\right)_{4}(2): E D T A(8: 32)$ & $61.91 \pm 3.24$ \\
\hline
\end{tabular}


Related to established biofilm treatment values, the effective combinations that eliminated biofilm cells (MBEC combination value), $\mathrm{ArCO}_{2} \mathrm{G}_{2}\left(\mathrm{SNMe}_{3} \mathrm{I}\right)_{4}$ (2):EDTA (256:16) and $\mathrm{ArCO}_{2} \mathrm{G}_{2}\left(\mathrm{SNMe}_{3} \mathrm{I}\right)_{4}(2): \mathrm{AgNO}_{3}$ (32:32), were cytotoxic against the cell line. Despite these cytotoxicity results, new molecules, such as silver nanoparticles or new combinations of EDTA with another similar dendron, could improve the cytotoxicity of the compounds, making them not only effective, but also less cytotoxic. In addition, these combinations could be completely useful for any other application that does not require direct human application, such as surface functionalization; and application in sanitizing or medical solutions (such as lotions).

\subsection{Alterations Produced in C. albicans Cells on Biofilms Due to $\mathrm{ArCO}_{2} \mathrm{G}_{2}\left(\mathrm{SNMe}_{3} \mathrm{I}_{4}\right.$ (2) Activity}

The alterations due to the action of $\mathrm{ArCO}_{2} \mathrm{G}_{2}\left(\mathrm{SNMe}_{3} \mathrm{I}\right)_{4}(2)$ and combinations tested in the biofilm formation and stablished biofilm experiments against $C$. albicans biofilms were visualized and confirmed by SEM. In the biofilm formation treatment, we observed a perfectly homogeneous biofilm formation with layers of cells with smooth and regular walls in the untreated C. albicans controls (Figure 3A). However, in the treated samples with the different compounds the absence of a uniform layer and disrupted biofilm could be observed, as consequence of decreased and/or inhibition of biofilm formation Figure 3B-F). In Figure 3B, it was observed that the dendron $\mathrm{ArCO}_{2} \mathrm{G}_{2}\left(\mathrm{SNMe}_{3} \mathrm{I}\right)_{4}(2)$, damaged the biofilm cells and the biofilm structure was highly reduced, even at a concentration lower than its MBIC. In the case of $\mathrm{AgNO}_{3}(\mathrm{MBIC}: 8 \mathrm{mg} / \mathrm{L})$, the destruction of the cells was observed (Figure 3C), in contrast to EDTA, that showed no differences compared to the control (Figure 3D). Our data indicated that for combinations $\mathrm{ArCO}_{2} \mathrm{G}_{2}\left(\mathrm{SNMe}_{3} \mathrm{I}\right)_{4}(2): \mathrm{AgNO}_{3}$ $(8: 4 \mathrm{mg} / \mathrm{L})$ and $\mathrm{ArCO}_{2} \mathrm{G}_{2}\left(\mathrm{SNMe}_{3} \mathrm{I}\right)_{4}(2)$ :EDTA $(8-32 \mathrm{mg} / \mathrm{L})$ the viability was approximately $25 \%$. These results were verified by SEM, where cells appeared collapsed (Figure 3E,F. Arrows) at these sub-MBIC concentrations.
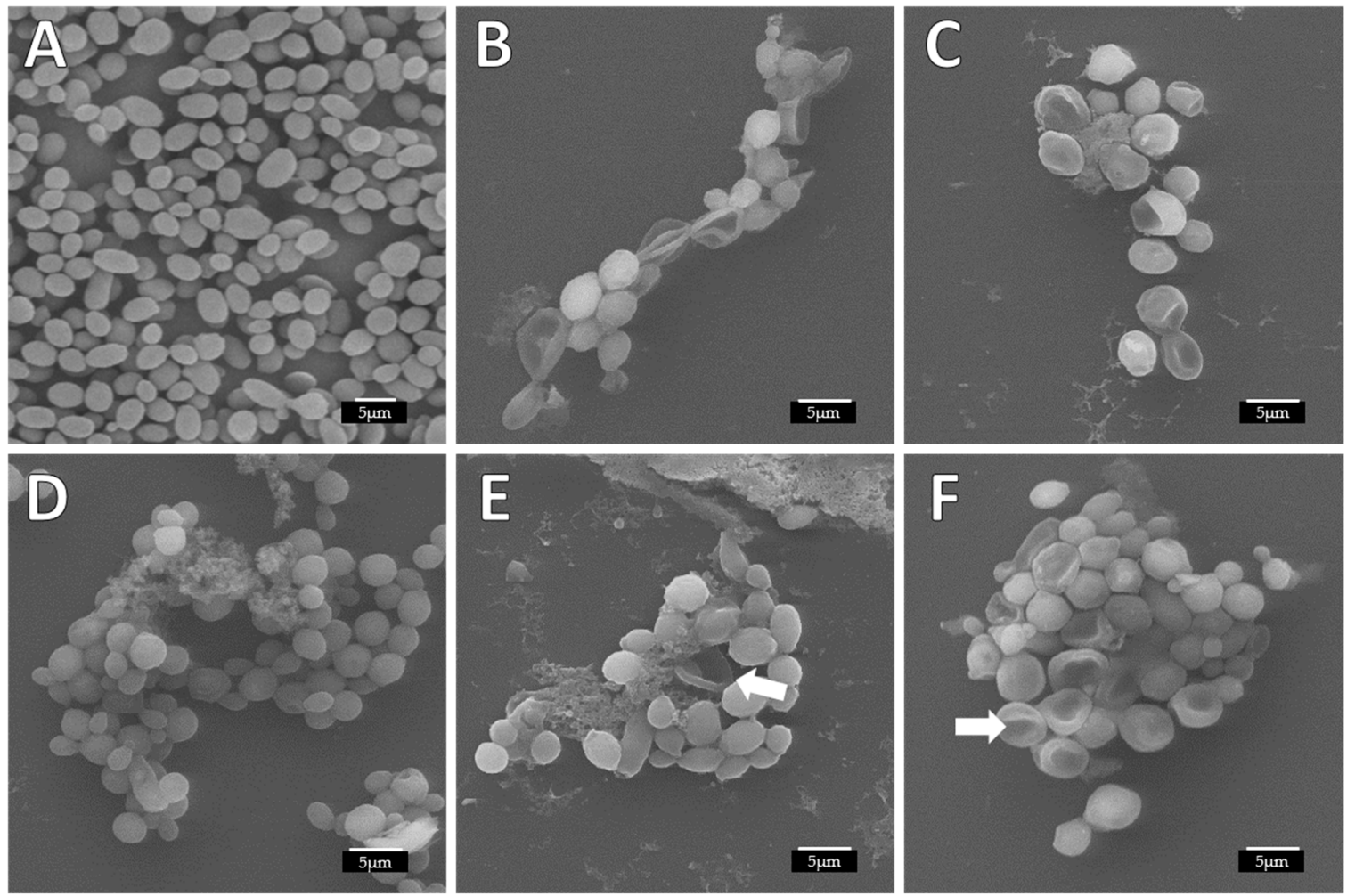

Figure 3. Alterations produced in C. albicans biofilm structure and cell morphology during the biofilm formation treatment observed by SEM. (A) Untreated; (B) $\mathrm{ArCO}_{2} \mathrm{G}_{2}\left(\mathrm{SNMe}_{3} \mathrm{I}\right)_{4}$ (2) dendron alone to $8 \mathrm{mg} / \mathrm{L}$ (C) $\mathrm{AgNO}_{3}$ alone to $8 \mathrm{mg} / \mathrm{L}$; (D) EDTA alone to $32 \mathrm{mg} / \mathrm{L} ;\left(\right.$ E) combination $\mathrm{ArCO}_{2} \mathrm{G}_{2}\left(\mathrm{SNMe}_{3} \mathrm{I}\right)_{4}(2): \mathrm{AgNO}_{3}$ to $8: 4 \mathrm{mg} / \mathrm{L} ;(\mathbf{F})$ combination $\mathrm{ArCO}_{2} \mathrm{G}_{2}\left(\mathrm{SNMe}_{3} \mathrm{I}\right)_{4}$ (2):EDTA to 8:32 mg/L (white arrow: collapsed cells). 
The biofilms were also evaluated in the established biofilm. Again, differences were seen in the homogeneity of the control biofilm (Figure 4A) with respect to the treated C. albicans cells. The untreated biofilms displayed a uniform distribution, cells were attached to each other and showed a completely smooth membrane with a typical oval yeast shape. In contrast, treated biofilms previously formed with the compounds showed alterations (Figure 4B-F). The cellular damage caused by the dendron $\mathrm{ArCO}_{2} \mathrm{G}_{2}\left(\mathrm{SNMe}_{3} \mathrm{I}\right)_{4}(2)$ was seen as deformation on the cell wall and yeast morphology (Figure 4B, arrow: cells collapsed). These alterations were similar to the alterations previously described with the BDSQ024 dendrimer [9]. These biofilm disruptions and cell alterations has been observed in other studies [8]. In addition, we observed that yeast cells continue to attach to each other forming small groups of cells. This observation has been also reported [54]. In their study, they observed that biofilms treated with nanoparticles showed small multibranched groups of cells, usually formed by less than 10 cells. $\mathrm{AgNO}_{3}$ and EDTA showed less alterations (Figure 4C,D), although with EDTA treatment, roughness in the membrane was detected at high concentrations $(256 \mathrm{mg} / \mathrm{L})$ (Figure 3D). Our results indicated that $\mathrm{ArCO}_{2} \mathrm{G}_{2}\left(\mathrm{SNMe}_{3} \mathrm{I}\right)_{4}$ (2) dendron tested in combination with $\mathrm{AgNO}_{3}$ or EDTA, produced a synergistic effect that completely eradicated $100 \%$ of viable cells. This destruction was reflected in Figure 3E, where abnormal cell morphology and significant cellular deterioration was observed. In the case of $\mathrm{ArCO}_{2} \mathrm{G}_{2}\left(\mathrm{SNMe}_{3} \mathrm{I}\right)_{4}$ (2):EDTA combination, a more compact but clearly destroyed and altered biofilm was observed, including cells with certain perforations (Figure 4F. Arrows).
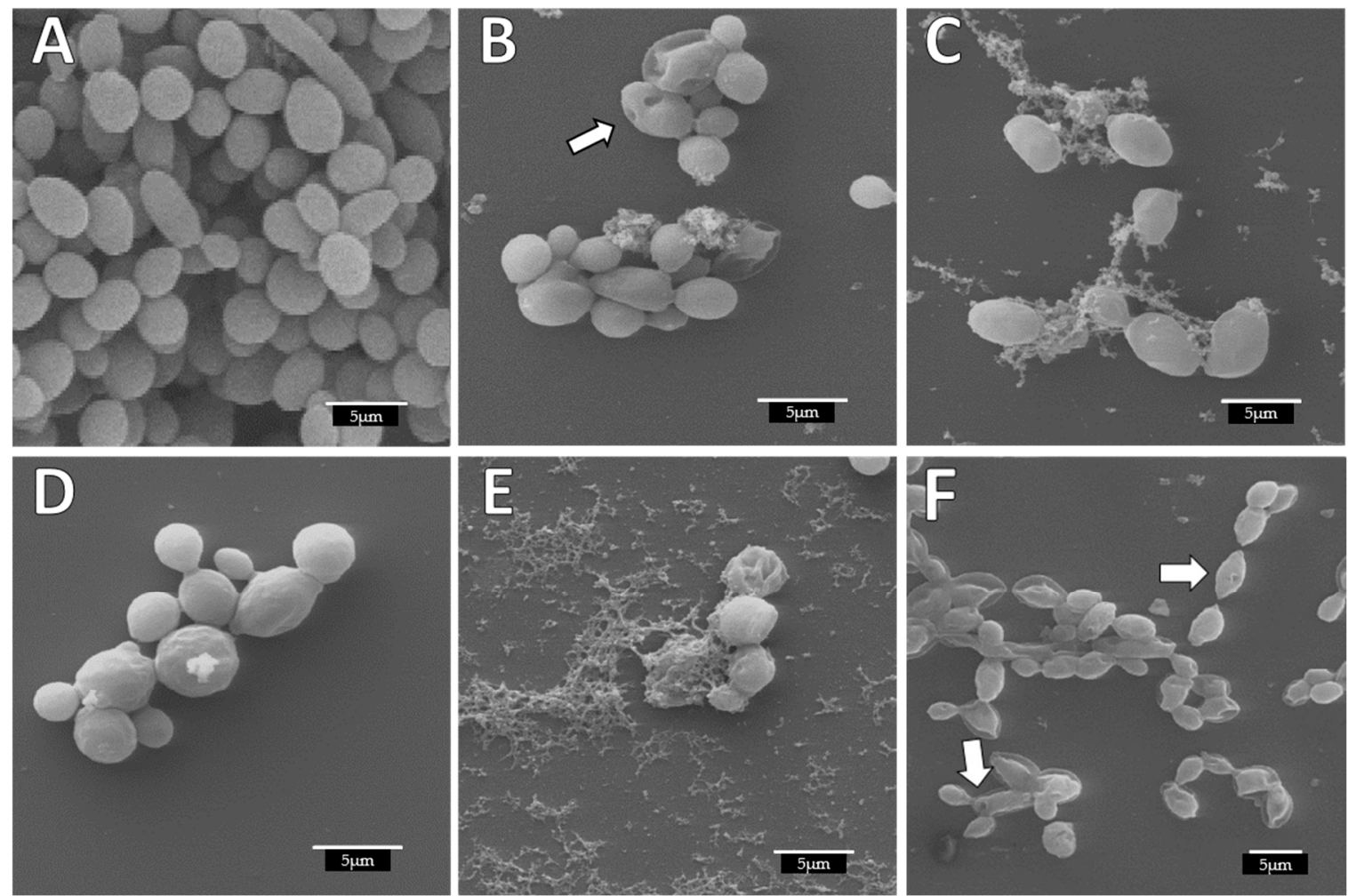

Figure 4. Alterations produced in C. albicans biofilm structure and cell morphology during the established biofilm-treatment observed by SEM. (A) Untreated; (B) $256 \mathrm{mg} / \mathrm{L} \mathrm{ArCO}_{2} \mathrm{G}_{2}\left(\mathrm{SNMe}_{3} \mathrm{I}\right)_{4}$ (2) dendron; (C) $32 \mathrm{mg} / \mathrm{L} \mathrm{AgNO}$; (D) $256 \mathrm{mg} / \mathrm{L}$ EDTA; (E) 32:32 mg/L combination $\mathrm{ArCO}_{2} \mathrm{G}_{2}\left(\mathrm{SNMe}_{3} \mathrm{I}\right)_{4}$ (2): $\mathrm{AgNO}_{3} ;$ (F) 256:32 mg/L combination $\mathrm{ArCO}_{2} \mathrm{G}_{2}\left(\mathrm{SNMe}_{3} \mathrm{I}\right)_{4}$ (2):EDTA (white arrow: collapsed cells).

\section{Conclusions}

In the present study, we found an effective cationic carbosilane dendron $\mathrm{ArCO}_{2} \mathrm{G}_{2}$ $\left(\mathrm{SNMe}_{3} \mathrm{I}_{4}(2)\right.$ with a 4-phenyl butyric (PBA) at the focal point and four ammonium groups 
on the surface groups, capable of preventing biofilm formation and damaging Candida albicans biofilms. The activity of this compound is comparable to some antifungal drugs and it could be used to control the nosocomial spread of this pathogen, especially in hospitalized patients. Therefore, we suggest that it may be used in healthcare, as a sanitizer solution for surfaces or a lotion to control skin infections. Additionally, we have managed to seriously damage an already formed biofilm, eradicating cell viability in its entirety using different combinations of dendron together with EDTA and $\mathrm{AgNO}_{3}$. These compounds could be also applied in the biomedical field with the objective of functionalized surfaces. Effective concentrations showed some cytotoxicity but the aim in future studies is to reduce cytotoxicity studying either new structures of the dendrons analysed in this study or other kind of dendrimers.

Author Contributions: Conceptualization, N.G.-C., I.H.-B., J.L.C.-P. and R.G.; methodology, J.L.C.-P., I.H.-B., N.G.-C. and P.O.; formal analysis and investigation, N.G.-C., I.H.-B. and T.L.-C.; data curation, N.G.-C., I.H.-B., J.L.C.-P. and J.S.; writing-original draft preparation, N.G.-C., I.H.-B. and P.O.; writing-review and editing, all authors; funding acquisition, R.G., I.H.-B. and J.L.C.-P.; resources, all authors; supervision: I.H.-B. and J.L.C.-P. All authors have read and agreed to the published version of the manuscript.

Funding: This research was funded by grants from CTQ2017-86224-P (MINECO), consortium NANODENDMED II-CM ref B2017/BMD-3703 Comunidad de Madrid-CAM, CCG19/CCS-022 and CCG20CCS-013 (University of Acalá), CM/JIN/2019-020 (Comunidad de Madrid-CAM). NGC wishes to thank CAM for a contract linked to NANODENDMED-II (CONMICDEN) project. CIBERBBN is an initiative funded by the VI National R \& D \& I Plan 2008-2011, Iniciativa Ingenio 2010, Consolider Program, CIBER Actions and financed by the Instituto de Salud Carlos III with assistance from the European Regional Development Fund.

Institutional Review Board Statement: Not applicable.

Informed Consent Statement: Not applicable.

Acknowledgments: We wish to thank Isabel Trabado and Cristina de Miguel (Cell culture Unit-CAI Medicina y Biología de la Universidad de Alcalá) for providing HeLa cell line; and Antonio Priego and José Antonio Pérez (Microscopy Unit-CAI Medicina y Biología de la Universidad de Alcalá) for assistance with electron microscopy observations.

Conflicts of Interest: The authors declare no conflict of interest.

\section{References}

1. Nobile, C.; Mitchell, A.P. Genetics and genomics of Candida albicans biofilm formation. Cell. Microbiol. 2006, 8, $1382-1391$. [CrossRef]

2. Nobile, C.J.; Johnson, A.D. Candida albicansBiofilms and Human Disease. Annu. Rev. Microbiol. 2015, 69, 71-92. [CrossRef]

3. Gökmenoglu, C.; Kara, N.B.; Beldüz, M.; Kamburoğlu, A.; Tosun, I.; Sadik, E.; Kara, C. Evaluation of Candida Albicans biofilm formation on various parts of implant material surfaces. Niger. J. Clin. Pract. 2018, 21, 33-37. [CrossRef]

4. Bouza, E.; Guinea, J.; Guembe, M. The Role of Antifungals against Candida Biofilm in Catheter-Related Candidemia. Antibiotics 2014, 4, 1-17. [CrossRef]

5. Uppuluri, P.; Pierce, C.; López-Ribot, J.L. Candida albicansbiofilm formation and its clinical consequences. Future Microbiol. 2009, 4, 1235-1237. [CrossRef] [PubMed]

6. Ramage, G.; Saville, S.P.; Thomas, D.P.; López-Ribot, J.L. Candida Biofilms: An Update. Eukaryot. Cell 2005, 4, 633-638. [CrossRef]

7. Gulati, M.; Nobile, C.J. Candida albicans biofilms: Development, regulation, and molecular mechanisms. Microbes Infect. 2016, 18, 310-321. [CrossRef]

8. Lara, H.H.; Romero-Urbina, D.G.; Pierce, C.; Lopez-Ribot, J.; Arellano-Jiménez, M.J.; Jose-Yacaman, M. Effect of silver nanoparticles on Candida albicans biofilms: An ultrastructural study. J. Nanobiotechnol. 2015, 13, 1-12. [CrossRef] [PubMed]

9. Heredero-Bermejo, I.; Gómez-Casanova, N.; Quintana, S.; Soliveri, J.; De La Mata, F.; Serrano, J.P.; Sánchez-Nieves, J.; Copa-Patiño, J. In Vitro Activity of Carbosilane Cationic Dendritic Molecules on Prevention and Treatment of Candida Albicans Biofilms. Pharmaceutics 2020, 12, 918. [CrossRef] [PubMed]

10. Abbasi, E.; Aval, S.F.; Akbarzadeh, A.; Milani, M.; Nasrabadi, H.T.; Joo, S.W.; Hanifehpour, Y.; Nejati-Koshki, K.; Pashaei-Asl, R. Dendrimers: Synthesis, applications, and properties. Nanoscale Res. Lett. 2014, 9, 247. [CrossRef] [PubMed]

11. Chis, A.A.; Dobrea, C.; Morgovan, C.; Arseniu, A.M.; Rus, L.L.; Butuca, A.; Juncan, A.M.; Totan, M.; Vonica-Tincu, A.L.; Cormos, G.; et al. Applications and Limitations of Dendrimers in Biomedicine. Molecules 2020, 25, 3982. [CrossRef] [PubMed] 
12. Polcyn, P.; Jurczak, M.; Rajnisz, A.; Solecka, J.; Urbanczyk-Lipkowska, Z. Design of Antimicrobially Active Small Amphiphilic Peptide Dendrimers. Molecules 2009, 14, 3881-3905. [CrossRef] [PubMed]

13. Janiszewska, J.; Sowińska, M.; Rajnisz, A.; Solecka, J.; Łacka, I.; Milewski, S.; Urbanczyk-Lipkowska, Z. Novel dendrimeric lipopeptides with antifungal activity. Bioorg. Med. Chem. Lett. 2012, 22, 1388-1393. [CrossRef]

14. Winnicka, K.; Wróblewska, M.; Wieczorek, P.; Sacha, P.T.; Tryniszewska, E. Hydrogel of Ketoconazole and PAMAM Dendrimers: Formulation and Antifungal Activity. Molecules 2012, 17, 4612-4624. [CrossRef]

15. Stolarska, M.; Gucwa, K.; Urbańczyk-Lipkowska, Z.; Andruszkiewicz, R. Peptide dendrimers as antifungal agents and carriers for potential antifungal agent-N3-(4-methoxyfumaroyl)-(S)-2,3-diaminopropanoic acid-Synthesis and antimicrobial activity. J. Pept. Sci. 2019, 26. [CrossRef]

16. Zielińska, P.; Staniszewska, M.; Bondaryk, M.; Koronkiewicz, M.; Urbańczyk-Lipkowska, Z. Design and studies of multiple mechanism of anti-Candida activity of a new potent Trp-rich peptide dendrimers. Eur. J. Med. Chem. 2015, 105, 106-119. [CrossRef] [PubMed]

17. Fuentes-Paniagua, E.; Sánchez-Nieves, J.; Hernández-Ros, J.M.; Fernández-Ezequiel, A.; Soliveri, J.; Copa-Patiño, J.L.; Gómez, R.; de la Mata, F.J. Structure-activity relationship study of cationic carbosilane dendritic systems as antibacterial agents. RSC Adv. 2016, 6, 7022-7033. [CrossRef]

18. Winnicka, K.; Sosnowska, K.; Wieczorek, P.; Sacha, P.; Tryniszewska, E. Poly(amidoamine) Dendrimers Increase Antifungal Activity of Clotrimazole. Biol. Pharm. Bull. 2011, 34, 1129-1133. [CrossRef] [PubMed]

19. Gorain, B.; Pandey, M.; Choudhury, H.; Jain, G.K.; Kesharwani, P. Dendrimer for Solubility Enhancement; Dendrimer-Based Nanotherapeutics; Academic Press: Cambridge, MA, USA, 2021; pp. 273-283.

20. Mallmann, E.J.J.; Cunha, A.; Castro, B.N.; Maciel, A.M.; Menezes, E.A.; Fechine, P.B.A. Antifungal Activity OF Silver Nanoparticles Obtained by Green Synthesis. Rev. Inst. Med. Trop. São Paulo 2015, 57, 165-167. [CrossRef] [PubMed]

21. Fakhruddin, K.S.; Egusa, H.; Ngo, H.C.; Panduwawala, C.; Pesee, S.; Venkatachalam, T.; Samaranayake, L.P. Silver diamine fluoride (SDF) used in childhood caries management has potent antifungal activity against oral Candida species. BMC Microbiol. 2020, 20, 95. [CrossRef] [PubMed]

22. Gao, S.S.; Zhao, I.S.; Duffin, S.; Duangthip, D.; Lo, E.C.M.; Chu, C.H. Revitalising Silver Nitrate for Caries Management. Int. J. Environ. Res. Public Health 2018, 15, 80. [CrossRef]

23. Atiyeh, B.S.; Costagliola, M.; Hayek, S.N.; Dibo, S.A. Effect of silver on burn wound infection control and healing: Review of the literature. Burns 2007, 33, 139-148. [CrossRef]

24. Ammons, M.C.B.; Ward, L.S.; James, G.A. Anti-biofilm efficacy of a lactoferrin/xylitol wound hydrogel used in combination with silver wound dressings. Int. Wound J. 2011, 8, 268-273. [CrossRef] [PubMed]

25. Moir, J.; Serra, M.P. The use of silver nitrate in wound management. Ann. Ital. Chir. 2012, 83, 45-48. [PubMed]

26. Lin, S.; Huang, R.; Cheng, Y.; Liu, J.; Lau, B.L.; Wiesner, M.R. Silver nanoparticle-alginate composite beads for point-of-use drinking water disinfection. Water Res. 2013, 47, 3959-3965. [CrossRef] [PubMed]

27. Besinis, A.; De Peralta, T.; Handy, R.D. Inhibition of biofilm formation and antibacterial properties of a silver nano-coating on human dentine. Nanotoxicology 2013, 8, 1-10. [CrossRef] [PubMed]

28. Juda, M.; Paprota, K.; Jałoza, D.; Malm, A.; Rybojad, P.; Goździuk, K. EDTA as a potential agent preventing formation of Staphylococcus epidermidis biofilm on polichloride vinyl biomaterials. Ann. Agric. Environ. Med. 2008, 15, $237-241$.

29. Chang, Y.; Gu, W.; McLandsborough, L. Low concentration of ethylenediaminetetraacetic acid (EDTA) affects biofilm formation of Listeria monocytogenes by inhibiting its initial adherence. Food Microbiol. 2012, 29, 10-17. [CrossRef]

30. Cavaliere, R.; Ball, J.L.; Turnbull, L.; Whitchurch, C.B. The biofilm matrix destabilizers, EDTA and DN aseI, enhance the susceptibility of nontypeable Hemophilus influenzae biofilms to treatment with ampicillin and ciprofloxacin. Microbiologyopen 2014, 3, 557-567. [CrossRef] [PubMed]

31. Finnegan, S.; Percival, S. EDTA: An Antimicrobial and Antibiofilm Agent for Use in Wound Care. Adv. Wound Care 2015, 4, 415-421. [CrossRef]

32. Liu, F.; Hansra, S.; Crockford, G.; Köster, W.; Allan, B.J.; Blondeau, J.M.; Lainesse, C.; White, A.P. Tetrasodium EDTA Is Effective at Eradicating Biofilms Formed by Clinically Relevant Microorganisms from Patients' Central Venous Catheters. mSphere 2018, 3, e00525-18. [CrossRef]

33. Lozano-Cruz, T.; Alcarraz-Vizán, G.; De La Mata, J.; De Pablo, S.; Ortega, P.; Duarte, Y.; Bravo-Moraga, F.; González-Nilo, F.D.; Novials, A.; Gómez, R. Cationic Carbosilane Dendritic Systems as Promising Anti-Amyloid Agents in Type 2 Diabetes. Chem. A Eur. J. 2020, 26, 7609-7621. [CrossRef] [PubMed]

34. Ramage, G.; Walle, K.V.; Wickes, B.; López-Ribot, J.L. Standardized Method for In Vitro Antifungal Susceptibility Testing of Candida albicans Biofilms. Antimicrob. Agents Chemother. 2001, 45, 2475-2479. [CrossRef] [PubMed]

35. National Committee for Clinical Laboratory Standards. Method for Broth Dilution Antifungal Susceptibility Testing of Yeasts: Approved Standard M27-A; NCCLS: Wayne, PA, USA, 1997.

36. Ravi, N.S.; Aslam, R.F.; Veeraraghavan, B. A New Method for Determination of Minimum Biofilm Eradication Concentration for Accurate Antimicrobial Therapy. Adv. Struct. Saf. Stud. 2019, 1946, 61-67. [CrossRef]

37. Kohno, Y.; Ohno, H.; Miyazaki, Y.; Higashiyama, Y.; Yanagihara, K.; Hirakata, Y.; Fukushima, K.; Kohno, S. In Vitro and In Vivo Activities of Novel Fluoroquinolones Alone and in Combination with Clarithromycin against Clinically Isolated Mycobacterium avium Complex Strains in Japan. Antimicrob. Agents Chemother. 2007, 51, 4071-4076. [CrossRef] [PubMed] 
38. Kerekes, E.-B.; Deák, É.; Takó, M.; Tserennadmid, R.; Petkovits, T.; Vágvölgyi, C.; Krisch, J. Anti-biofilm forming and anti-quorum sensing activity of selected essential oils and their main components on food-related micro-organisms. J. Appl. Microbiol. 2013, 115, 933-942. [CrossRef] [PubMed]

39. Mahmoudabadi, A.Z.; Zarrin, M.; Kiasat, N. Biofilm Formation and Susceptibility to Amphotericin B and Fluconazole in Candida albicans. Jundishapur J. Microbiol. 2014, 7, e17105. [CrossRef]

40. Thomas, P.; Sekhar, A.C.; Upreti, R.; Mujawar, M.M.; Pasha, S.S. Optimization of single plate-serial dilution spotting (SP-SDS) with sample anchoring as an assured method for bacterial and yeast cfu enumeration and single colony isolation from diverse samples. Biotechnol. Rep. 2015, 8, 45-55. [CrossRef]

41. Heredero-Bermejo, I.; Sánchez-Nieves, J.; Soliveri, J.; Gómez, R.; de la Mata, F.; Copa-Patiño, J.L.; Serrano, J.P. In vitro antiAcanthamoeba synergistic effect of chlorhexidine and cationic carbosilane dendrimers against both trophozoite and cyst forms. Int. J. Pharm. 2016, 509, 1-7. [CrossRef]

42. Kolb, P.S.; Ayaub, E.A.; Zhou, W.; Yum, V.; Dickhout, J.G.; Ask, K. The therapeutic effects of 4-phenylbutyric acid in maintaining proteostasis. Int. J. Biochem. Cell Biol. 2015, 61, 45-52. [CrossRef]

43. Sarker, P.; Ahmed, S.; Tiash, S.; Rekha, R.S.; Stromberg, R.; Andersson, J.; Bergman, P.; Gudmundsson, G.H.; Agerberth, B.; Raqib, R. Phenylbutyrate Counteracts Shigella Mediated Downregulation of Cathelicidin in Rabbit Lung and Intestinal Epithelia: A Potential Therapeutic Strategy. PLoS ONE 2011, 6, e20637. [CrossRef]

44. Jellbauer, S.; Lopez, A.P.; Behnsen, J.; Gao, N.; Nguyen, T.; Murphy, C.; Edwards, R.A.; Raffatellu, M. Beneficial Effects of Sodium Phenylbutyrate Administration during Infection with Salmonella enterica Serovar Typhimurium. Infect. Immun. 2016, 84, 2639-2652. [CrossRef]

45. Lo, C.-Y.; Cheng, H.-L.; Hsu, J.-L.; Liao, M.-H.; Yen, R.-L.; Chen, Y.-C. The Antimicrobial Activities of Phenylbutyrates against Helicobacter pylori. Chem. Pharm. Bull. 2013, 61, 604-610. [CrossRef]

46. Yadavalli, T.; Suryawanshi, R.; Koganti, R.; Hopkins, J.; Ames, J.; Koujah, L.; Iqbal, A.; Madavaraju, K.; Agelidis, A.; Shukla, D. Standalone or combinatorial phenylbutyrate therapy shows excellent antiviral activity and mimics CREB3 silencing. Sci. Adv. 2020, 6, eabd9443. [CrossRef] [PubMed]

47. Spadari, C.; Lopes, L.; Ishida, K. Potential Use of Alginate-Based Carriers As Antifungal Delivery System. Front. Microbiol. 2017, 8, 97. [CrossRef] [PubMed]

48. Tulu, M.; Aghatabay, N.M.; Senel, M.; Dizman, C.; Parali, T.; Dulger, B. Synthesis, characterization and antimicrobial activity of water soluble dendritic macromolecules. Eur. J. Med. Chem. 2009, 44, 1093-1099. [CrossRef] [PubMed]

49. Turan, H.; Demirbilek, M. Biofilm-forming capacity of blood-borne Candida albicans strains and effects of antifungal agents. Rev. Argent. Microbiol. 2018, 50, 62-69. [CrossRef]

50. Berkow, E.L.; Lockhart, S.R. Fluconazole resistance in Candida species: A current perspective. Infect. Drug Resist. 2017, 10, 237-245. [CrossRef] [PubMed]

51. Chen, C.Z.; Cooper, S.L. Interactions between dendrimer biocides and bacterial membranes. Biomaterials 2002, $23,3359-3368$. [CrossRef]

52. Heredero-Bermejo, I.; Hernández-Ros, J.M.; Sánchez-García, L.; Maly, M.; Verdu, C.; Soliveri, J.; de la Mata, F.J.; Copa-Patiño, J.L.; Serrano, J.P.; Sánchez-Nieves, J.; et al. Ammonium and guanidine carbosilane dendrimers and dendrons as microbicides. Eur. Polym. J. 2018, 101, 159-168. [CrossRef]

53. Ortega, M.; Merino, A.G.; Fraile-Martínez, O.; Recio-Ruiz, J.; Pekarek, L.; Guijarro, L.G.; García-Honduvilla, N.; Álvarez-Mon, M.; Buján, J.; García-Gallego, S. Dendrimers and Dendritic Materials: From Laboratory to Medical Practice in Infectious Diseases. Pharmaceutics 2020, 12, 874. [CrossRef]

54. Vazquez-Munoz, R.; Lopez, F.D.; Lopez-Ribot, J.L. Silver Nanoantibiotics Display Strong Antifungal Activity against the Emergent Multidrug-Resistant Yeast Candida auris Under Both Planktonic and Biofilm Growing Conditions. Front. Microbiol. 2020, 11, 1673. [CrossRef]

55. LaFleur, M.D.; Kumamoto, C.A.; Lewis, K. Candida albicans Biofilms Produce Antifungal-Tolerant Persister Cells. Antimicrob. Agents Chemother. 2006, 50, 3839-3846. [CrossRef]

56. Wuyts, J.; Van Dijck, P.; Holtappels, M. Fungal persister cells: The basis for recalcitrant infections? PLoS Pathog. 2018, 14, e1007301. [CrossRef] [PubMed]

57. Alshahni, R.Z.; Alshahni, M.M.; Hiraishi, N.; Makimura, K.; Tagami, J. Effect of Silver Diamine Fluoride on Reducing Candida albicans Adhesion on Dentine. Mycopathologia 2020, 185, 691-698. [CrossRef] [PubMed]

58. Zhang, J.; Got, S.-R.; Yin, I.; Lo, E.; Chu, C.-H. A Concise Review of Silver Diamine Fluoride on Oral Biofilm. Appl. Sci. 2021, 11, 3232. [CrossRef]

59. Raad, I.; Hanna, H.; Dvorak, T.; Chaiban, G.; Hachem, R. Optimal Antimicrobial Catheter Lock Solution, Using Different Combinations of Minocycline, EDTA, and 25-Percent Ethanol, Rapidly Eradicates Organisms Embedded in Biofilm. Antimicrob. Agents Chemother. 2007, 51, 78-83. [CrossRef]

60. Reitzel, R.A.; Rosenblatt, J.; Gerges, B.Z.; Vargas-Cruz, N.; Raad, I.I. Minocycline-EDTA-Ethanol Antimicrobial Catheter Lock Solution Is Highly Effective In Vitro for Eradication of Candida auris Biofilms. Antimicrob. Agents Chemother. 2020, 64, e02146-19. [CrossRef] [PubMed] 